\title{
Pengembangan prototipe sistem pencatatan waktu untuk pengukuran kecepatan secara otomatis pada sprint 60-meter
}

\author{
Indria Herman $^{1 *}$, Tommy Apriantono ${ }^{1}$, Widyawardana Adiprawita ${ }^{1}$, Deni Kurnia One ${ }^{1}$, Diyar \\ Yasin $^{1}$, Syahruddin Syahruddin ${ }^{2}$, Bagus Winata ${ }^{1}$ \\ ${ }^{1}$ Institut Teknologi Bandung, Ganesha No.10, Lb. Siliwangi, Coblong, Kota Bandung, Jawa Barat, \\ 40132, Indonesia \\ ${ }^{2}$ Universitas Negeri Makassar, A. P. Pettarani, Tidung, Kec. Rappocini, Kota Makassar, Sulawesi \\ Selatan, 90222, Indonesia \\ * Corresponding Author. Email: wadiprawita@gmail.com
}

Received: July 17, 2020 ; Revised: September 29, 2020 ; Accepted: September 30, 2020

\begin{abstract}
Abstrak: Saat ini sedang berkembang pencatatan waktu otomatis yang dijual oleh beberapa perusahan perlatan olahraga ternama seperti. Namun sayangnya, harga perangkat tersebut sangatlah mahal, dan membuat setiap pelatih ataupun praktisi olahraga terkendala untuk mendapatkannya. Karena fakta dan permasalahan tersebut, maka penelitian ini bertujuan untuk mengembangkan prototipe sistem pencatatan waktu untuk pengukuran kecepatan secara otomatis pada sprint 60-meter, dengan menggunakan perangkat sederhana dengan harga yang murah, namun memiliki tingkat presisi dan akurasi yang baik. Penelitian ini menggunakan metode penelitian research and development, dimana dalam proses pengembangan dan pembuatan pencatatan waktu otomatis, penelitian ini mengambil contoh dari timing gate yang sudah divalidasi sebelumnya. Dalam penelitian ini, kami juga sudah melakukan uji coba kepada 12 atlet sprinter (tinggi badan 172.8 \pm 9.31 , berat badan $61.05 \pm 6.90$, BMI $20.38 \pm 0.87$ ) terkait kegunaan alat tersebut. Ratarata kecepatan lari seluruh subjek pada pos 10-meter adalah $2.44 \pm 0.23$ detik, pos 20 -meter adalah $3.71 \pm$ 0.18 detik, pos 30 -meter adalah $4.75 \pm 0.22$ detik, pos 40 -meter adalah $6.39 \pm 0.31$ detik, 50 -meter adalah $7.65 \pm 0.41$ detik, dan 60-meter adalah $9.12 \pm 0.49$ detik. Penelitian research and development terkait pengembangan pencatatan waktu otomatis dalam penelitian ini, menunjukkan bahwa pencatatan waktu otomatis dapat dibuat dengan harga ekonomis, dan dapat digunakan untuk mengukur kecepatan lari 60-meter.

Kata Kunci: kecepatan, peralatan olahraga, prototipe, sports science, sprinter
\end{abstract}

\section{Development of track timer prototype system for automatic speed measurement on 60-meter sprints}

\begin{abstract}
Currently, automatic track timers are being sold by several well-known sports equipment companies. Unfortunately, the price of the device is very expensive and makes every coach or practitioner constrained to get it. Because of these facts and problems, this research was aimed to develop a prototype track timer system for automatic speed measurement on a 60-meter sprint, using a simple device at a low price, but has a good level of precision and accuracy. This study used to research and development research methods, wherein the process of developing and manufacturing automatic track timers, this study takes the example of a timing gate that has been validated before. In this study, we have also tested 12 sprinters (height $172.8 \pm 9.31$, weight $61.05 \pm 6.90$, BMI $20.38 \pm 0.87$ ) related to the use of the tools. The average running speed of all subjects on a 10-meter post is $2.44 \pm 0.23$ seconds, a 20-meter post is $3.71 \pm 0.18$ seconds, a 30 meter post is $4.75 \pm 0.22$ seconds, a 40-meter post is $6.39 \pm 0.31$ seconds, 50 - The meter is $7.65 \pm 0.41$ seconds, and the 60-meter is $9.12 \pm 0.49$ seconds. This research shows that track timers can be made at economical prices, and can be used to measure 60-meter running speed.
\end{abstract}

Keyword: speed, sports equipment, prototype, sports science, sprinter

How to Cite: Herman, I, Apriantono, T., Adiprawita, W., One, D. K., Yasin, D, Syahruddin, S., \& Winata, B. (2021). Pengembangan prototipe sistem pencatatan waktu untuk pengukuran kecepatan secara otomatis pada sprint 60-meter. Jurnal Keolahragaan, 9(1), 35-42, doi: https://doi.org/10.21831/jk.v9i1.33356 
Jurnal Keolahragaan 9 (1), 2021 - 36

Indria Herman, Tommy Apriantono, Widyawardana Adiprawita, Deni Kurnia One, Diyar Yasin, Syahruddin

Syahruddin, Bagus Winata

\section{PENDAHULUAN}

Pertumbuhan olahraga di Indonesia sejauh ini sedang mengalami perkembangan yang cukup signifikan. Hal ini dapat terlihat daripada beberapa ajang kompetisi Internasional seperti Asian Games, yang telah dipercayakan oleh International Olympic Committee (IOC) kepada Indonesia pada tahun 2018 silam (Tiffany \& Azmi, 2020). Dampak daripada terselenggaranya ajang kompetisi tersebut, tentunya menumbuhkan minat yang cukup kuat bagi setiap pelatih, ataupun praktisi olahraga lainnya dalam menemukan, dan membina calon-calon atlet, agar dapat mengharumkan nama baik Indonesia di kanca Internasional. Hal tersebut sangat beralasan, mengingat dengan menemukan calon bibit atlet yang tepat dan memiliki potensi di dalam suatu cabang olahraga, maka diharapkan proses pembinaan yang nantinya akan diterapkan dapat berjalan dengan baik dan sesuai harapan para pelatih (Johnston, Wattie, Schorer, \& Baker, 2018).

Pada umumnya para pelatih ataupun praktisi olahraga dapat menemukan dan membina atlet dengan melakukan proses identifikasi bakat melalui beberapa test pengukuran performa seperti kecepatan, agility, flexibility, power, dan pengukuran performa lainnya (Jacob, Spiteri, Hart, \& Anderton, 2018; D. L. Mann, Dehghansai, \& Baker, 2017). Namun ada juga beberapa pelatih dan praktisi olahraga yang melakukan pengukuran karakteristik fisiologi seperti pengukuran kapasitas aerobik dan pengukuran kapasitas anaerobik sebagai dasar daripada pemilihan calon-calon atlet tersebut (Fornasiero et al., 2017; Venckunas et al., 2016). Namun, daripada dua hal tersebut (pengukuran performa dan pengukuran karakteristik fisiologi), pengukuran performa merupakan pengukuran yang sering digunakan oleh pelatih ataupun praktisi olahraga dalam menentukan calon bibit atlet daripada setiap cabang olahraga (Spathis, Connick, Beckman, Newcombe, \& Tweedy, 2015). Alasanya sangat sederhana, karena dengan pengukuran performa, dapat dilakukan dengan protokol yang sederhana dan tidak memerlukan biaya yang besar dalam proses pelaksanaanya (Storniolo, Pavei, \& Minetti, 2017).

Kecepatan merupakan salah satu komponen pengukuran dasar yang digunakan dalam proses identifikasi bakat atlet (Augen, Reitscha, \& Amozino, 2018). Hal tersebut sangat beralasan, mengingat dengan melakukan pengukuran kecepatan, setiap pelatih ataupun praktisi olahraga dapat melihat dan mengetahui kapasitas anaerobik, tingkat akselerasi, dan tingkat daya tahan kecepatan daripada suatu individu (Haugen, Seiler, Sandbakk, \& Tønnessen, 2019; Nagahara, Mizutani, Matsuo, Kanehisa, \& Fukunaga, 2018). Dalam proses pengukurannya, kecepatan dapat diukur melalui test sprint jarak pendek dengan jarak 20-meter, 40-meter dan 60-meter (Haugen \& Buchheit, 2016; Hopker, Coleman, Wiles, \& Galbraith, 2009). Penentuan jarak yang digunakan sebagai test tersebut pada dasarnya mengacu kepada karakteristik jenis olahraga yang telah ditekuni. Dalam setiap pengukuran test sprint jarak pendek, biasanya setiap pelatih ataupun praktisi olahraga menggunakan stopwatch sebagai peralatan olahraga dalam menentukan hasil atau waktu tempuh daripada performa sprint seseorang.

Meskipun stopwatch dinilai paling efektif dalam menentukan hasil atau waktu tempuh dalam performa sprint, namun metode manual tersebut dinilai kurang presisi dalam memberikan hasil akhir (J. B. Mann, Ivey, Brechue, \& Mayhew, 2015). Hal tersebut dikarenakan hasil waktu yang diberikan oleh stopwatch sangat tergantung pada konsistensi dan kecepatan reaksi penguji dalam menekan tombol stopwatch (Hetzler, Stickley, Lundquist, \& Kimura, 2008). Mengingat setiap penguji memiliki perbedaan konsistensi dalam menekan tombol, hal tersebut membuat hasil waktu yang didapatkan masih dipertanyakan tingkat akurasinya, dan bahkan dapat menjadi suatu permasalahan perdebatan bagi setiap pelatih. Dampak lainnya adalah jika waktu yang didapatkan merupakan hasil daripada pengukuran yang tidak presisi, maka hal tersebut akan mempengaruhi hasil daripada identifikasi bakat yang nantinya akan dilakukan, dan hal tersebut akan membuat kerugian bagi seluruh pelatih ataupun calon bibit atlet (Bergkamp, Niessen, den Hartigh, Frencken, \& Meijer, 2018).

Di sisi lain, saat ini sedang berkembang pencatatan waktu otomatis yang dijual oleh beberapa perusahaan penyedia alat-alat keolahragaan ternama seperti fusion smart speed pro (Earp \& Newton, 2012). Kegunaan daripada pencatatan waktu otomatis tersebut adalah mengukur waktu kecepatan sprint seseorang dengan menggunakan prinsip sensor infrared ataupun beam photocell (Altmann et al., 2017). Hal tersebut membuat tingkat akurasi menjadi lebih baik dan tingkat human error menjadi lebih rendah, mengingat pencatatan waktu otomatis tersebut bekerja secara otomatis ketika sensor mendeteksi rangsang, dan bersifat wearable.(Zhang et al., 2018). Namun sayangnya, harga perangkat tersebut sangatlah mahal, dan membuat setiap pelatih ataupun praktisi olahraga terkendala untuk mendapatkannya. Karena fakta dan permasalahan tersebut, maka penelitian ini bertujuan untuk 
Jurnal Keolahragaan 9 (1), 2021 - 37

Indria Herman, Tommy Apriantono, Widyawardana Adiprawita, Deni Kurnia One, Diyar Yasin, Syahruddin

Syahruddin, Bagus Winata

mengembangkan prototipe sistem pencatatan waktu untuk pengukuran kecepatan secara otomatis pada sprint 60-meter, dengan menggunakan perangkat sederhana dengan harga yang murah, namun memiliki tingkat presisi dan akurasi yang baik. Harapannya dengan pengembangan prototipe pencatatan waktu otomatis ini, setiap pelatih ataupun praktisi olahraga dapat meendapatkannya dan menggunakannya dalam proses identifikasi bakat ataupun proses pembinaan atlet.

\section{METODE}

\section{Objek Penelitian}

Penelitian ini menggunakan metode penelitian research and development (R\&D). Secara lebih detail $R \& D$ adalah kegiatan penelitian, dan pengembangan, dan memiliki kepentingan komersial dalam kaitannya dengan riset ilmiah murni, dan pengembangan aplikatif di bidang teknologi. Dimana dalam proses pengembangan dan pembuatan pencatatan waktu otomatis, penelitian ini mengambil contoh dari timing gate yang sudah divalidasi sebelumnya. Namun yang menjadi kebaharuan dalam penelitian ini adalah, kami membuat sebanyak tujuh (7) pencatatan waktu otomatis yang meliputi pencatatan waktu otomatis pada garis start, 10-meter, 20-meter, 30-meter, 40-meter, 50-meter, 60-meter (Ilustrasi pemasangan perangkat, dapat dilihat pada gambar 1). Tentunya hal tersebut sangat berbeda dengam dari timing gate tervalidasi yang hanya dilengkapi pencatatan waktu otomatis sebanyak dua (2) saja, yang terletak pada garis start dan garis finish. Hal lain yang menjadi keunggulan dalam penelitian pengembangan ini adalah, penelitian ini menggunakan bahan dan material yang memiliki akurasi yang sama baiknya dengan timing gate yang sudah tervalidasi tersebut, namun dirancang dengan harga yang ekonomis. Dalam penelitian ini, kami juga sudah melakukan uji coba kepada 12 atlet sprinter (tinggi badan $172.8 \pm 9.31$, berat badan $61.05 \pm 6.90$, BMI $20.38 \pm 0.87$ ) terkait kegunaan alat tersebut. Dalam proses pelaksanaannya, seluruh subjek sudah mendapatkan penjelasan terkait proses uji coba yang akan mereka lakukan.

\section{Perancangan Alat}

Dalam proses perancangan alat ini, kami menggunakan beberapa material dalam perancangannya, seperti: Mikrokontroler ESP8266, yang dimaksudkan untuk pengontrol rangkaian elektronik dan umunya dapat menyimpan program didalamnya; sensor photoelectric yang dimaksudkan untuk menemukan jarak, ketidakhadiran, atau keberadaan suatu objek; lampu light emitting diode (LED) digunakan sebagai rangkaian lampu indikator terkait keberfungsian daripada kinerja pencatatan waktu otomatis; dalam proses komunikasinya, digunakan jaringan internet yang menghubungkan suatu perangkat pencatatan waktu otomatis dengan perangkat pencatatan waktu otomatis lainnya; dan untuk modul catu daya digunakan power bank untuk menghidupkan seluruh perangkat ketika proses pengoprasian perangkat tersebut. Desain pencatatan waktu otomatis dapat dilihat pada gambar 2. Dalam proses pemasangan pencatatan waktu otomatis digunakan 7 buah tripod sebagai penompang setiap pencatatan waktu otomatis yang terletak pada setiap pos. Tripod diletakkan dengan ketinggian 1 meter, dengan perhitungan ketinggan tersebut dapat memfasilitasi sensor photoelectric untuk menyentuh bagian tubuh peserta ketika melintas. Selanjutnya sensor tersebut akan membaca waktu ketika pelari melewati gelombang sensor di setiap gerbang pencatat waktu. Dalam proses perancangan alat, pencatatan waktu otomatis ini menghabiskan biaya sekitar Rp. 10 juta rupiah untuk total keseluruhan (1-unit perangkat) pencatatan waktu otomatis. Dengan harga tersebut, tentunya jauh lebih murah dibandingkan dengan timing gate system yang dijual oleh perusahaan penyedia alat olahraga, yang berada di rentang harga Rp 25 juta sampai dengan Rp 100 juta.

\section{Alur Penelitian}

7 gate pencatatan waktu diletakan pada garis start, 10-meter, 20-meter, 30-meter, 40-meter, 50meter, 60-meter. Setiap peserta melakukan uji coba sprint 60-meter sebanyak satu kali. Peserta berdiri di point start $(150-\mathrm{cm})$ dibelakang gate start. Announcer menghitung mundur 3-2-1 dan GO. Ketika mendengar GO, objek berlari semaksimal mungkin menuju garis finish yang berada pada point 60meter. 7 admministrator berada dibelakang setiap gate pencatatan waktu, untuk melakukan pengamatan terhadap infrared di setiap gate. Jika lampu indikator LED tidak bernyala maka peserta diminta untuk mengulang kembali melakukan performa sprint, hal itu dikarenakan sensor infrared tidak berfungsi dengan baik, sehingga diharuskan melakukan pengulangan. Di sisi lain, jika seluruh pengambilan data 


\section{Jurnal Keolahragaan 9 (1), 2021 - 38}

Indria Herman, Tommy Apriantono, Widyawardana Adiprawita, Deni Kurnia One, Diyar Yasin, Syahruddin Syahruddin, Bagus Winata

berjalan dengan baik, dan ketika peserta sudah melewati point 60-meter, administrator pada point tersebut harus berteriak "CLEAR", sebagai tanda bahwa peserta sudah menyelesaikan sprint dan tidak ada machine error yang terjadi.

\section{HASIL DAN PEMBAHASAN}

\section{Hasil}

Pada simulasi test yang telah dilakukan dalam penelitian ini, didapatkan hasil rata-rata lari seluruh sprinter di setiap pos pengukuran. Secara spesifik, dapat dijabarkan bahwa rata-rata kecepatan lari seluruh subjek pada pos 10-meter adalah $2.44 \pm 0.23$ detik, pos 20 -meter adalah $3.71 \pm 0.18$ detik, pos 30 -meter adalah $4.75 \pm 0.22$ detik, pos 40 -meter adalah $6.39 \pm 0.31$ detik, 50-meter adalah $7.65 \pm 0.41$ detik, dan 60-meter adalah $9.12 \pm 0.49$ detik. Hasil rata-rata lari seluruh subjek dapat dilihat pada tabel. 1 .

Tabel 1. Style dan Fungsinya

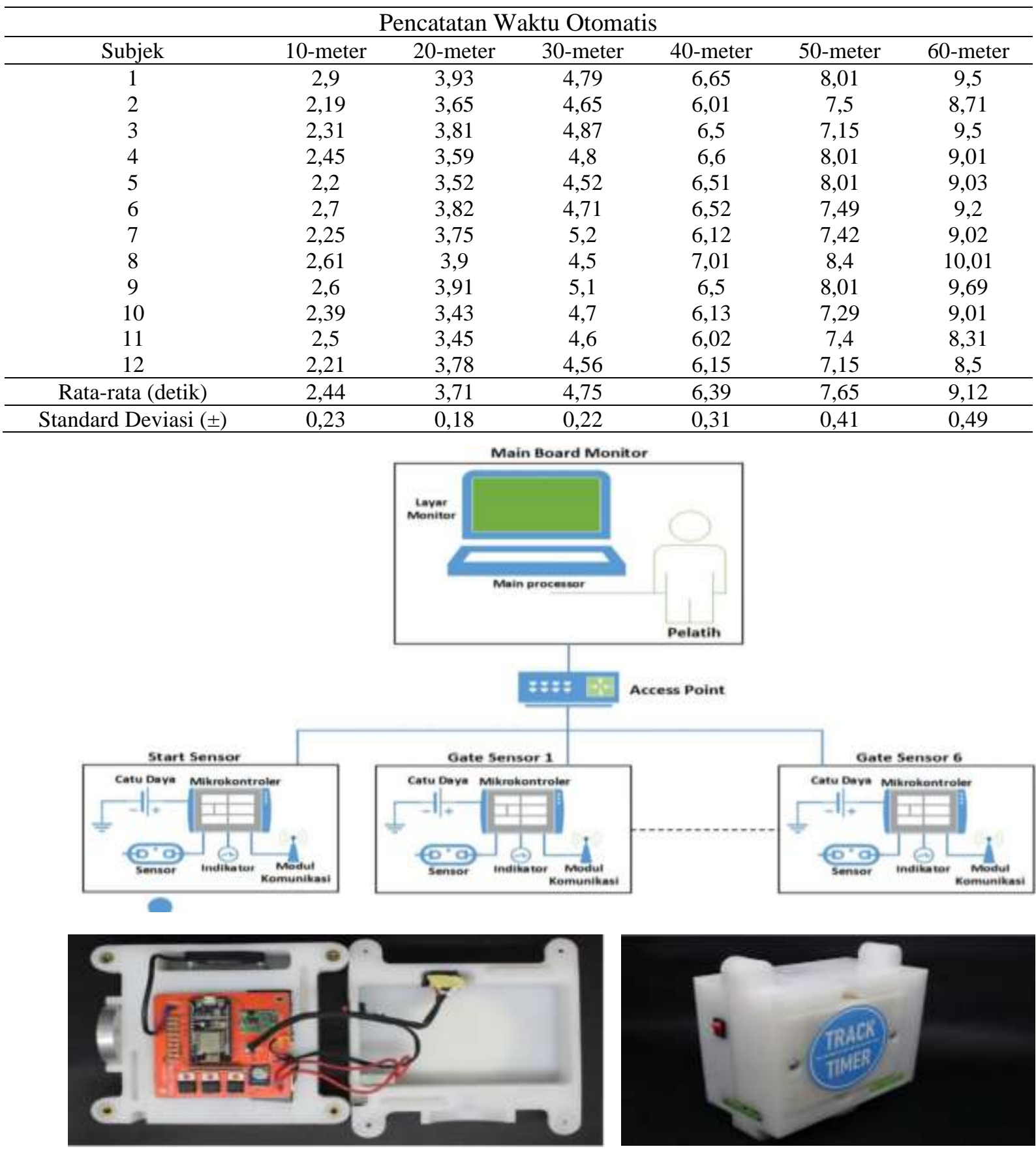


Jurnal Keolahragaan 9 (1), 2021 - 39

Indria Herman, Tommy Apriantono, Widyawardana Adiprawita, Deni Kurnia One, Diyar Yasin, Syahruddin Syahruddin, Bagus Winata

Gambar 1. Ilustrasi Pemasangan Perangkat

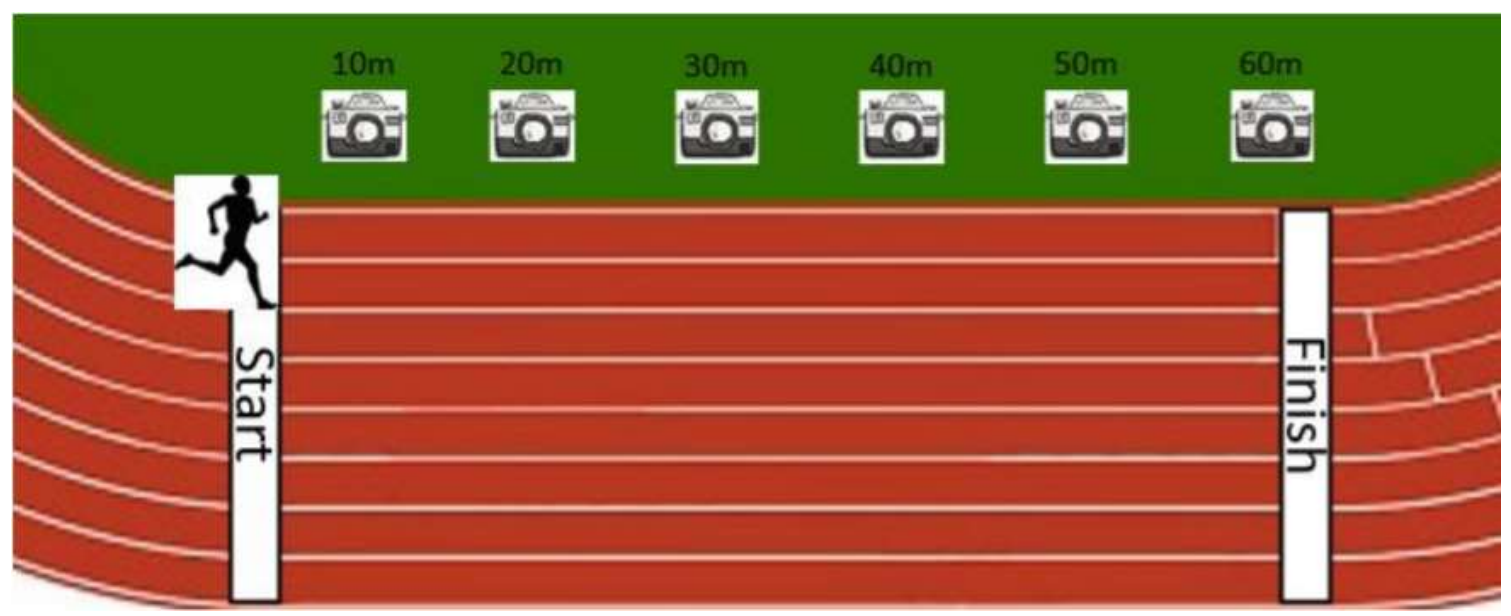

Gambar 2. Desain Pencatatan Waktu Otomatis

\section{Pembahasan}

Penelitian ini bertujuan untuk mengembangkan prototipe sistem pencatatan waktu otomatis untuk pengukuran kecepatan secara otomatis pada sprint 60-meter, dengan menggunakan perangkat sederhana dengan harga yang murah, namun dapat mendeteksi kecepatan secara baik. Sesuai dengan tujuan tersebut, penelitian ini berhasil menciptakan dan mengembangkan sistem pencatatan waktu otomatis dengan harga yang jauh lebih ekonomis. Hal ini terbukti dengan berhasilnya sistem pencatatan waktu otomatis dalam memberikan atau menjawab hasil rata-rata waktu 12 subjek di setiap pos ketika melakukan sprint 60-meter.

Penelitian ini, telah sejalan dengan penelitian pengembangan yang dilakukan oleh beberapa penelitian sebelumnya. Sebagai contoh, (Syahruddin, Imam, Lungit, Ramdan, \& Bagus, 2019) mengembangkan alat infrared sensor technology, dimana dalam alat tersebut mampu memfasilitasi setiap atlet, dan pelatih dalam menentukan jarak antara anterior superior iliac spine (ASIS) dengan jarak lantai ketika melakukan forward split test. Dengan adanya alat tersebut, tentunya para pelatih dan atlet telah meninggalkan cara yang manual, yaitu tidak perlu menggunakan penggaris, untuk mengukur jarak ASIS dengan lantai. Hal tersebut dikarenakan alat infrared sensor technology memiliki sifat pembacaan sensor yang mampu memberikan bantuan secara otomatis dalam menentukan jarak ASIS dengan lantai.

Timing gate merupakan sistem pencatatan waktu yang sudah digunakan oleh dunia keolahragaan sejak tahun 1960-1970 (Haugen \& Buchheit, 2016). Dalam prinsip penggunaanya timing gate, digunakan untuk membantu setiap perangkat pertandingan untuk melihat dan membuktikan secara kuantitatif terkait hasil kecepatan yang diperoleh oleh setiap pelari. Hal tersebut dilakukan untuk menentukan pemenang dari setiap kompetisi yang dilakukan. Namun sayangnya, penggunaan timing gate sangat jarang digunakan oleh praktisi olahraga dalam proses pembinaan ataupun identifikasi bakat atlet (Altmann et al., 2017). Sebaliknya, timing gate sering digunakan hanya ketika suatu kompetisi kelas dunia berlangsung. Hal ini cukup memprihatinkan, mengingat penggunaan timing gate sejatinya dapat digunakan sebagai alat yang dapat menunjang dan membantu pelatih ketika melakukan identifikasi bakat atlet ataupun ketika melakukan proses latihan. Pada umumnya, pelatih ataupun praktisi olahraga tidak memiliki biaya yang cukup untuk membeli timing gate, sehingga proses perhitungan waktu kecepatan atlet ditentukan dengan teknik manula menggunakan stopwatch (Haugen \& Buchheit, 2016; Haugen et al., 2019).

Stopwatch merupakan suatu alat yang alat yang digunakan untuk mengukur lamanya waktu yang diperlukan dalam kegiatan. Secara teori, penggunaan stopwatch sejatinya masih dapat diragukan dalam proses penentuan hasil akhir. Hal ini dikarenaka, penggunaan stopwatch, masih sangat tergantung kepada operator yang memegang kendali stopwatch tersebut. Sebagai contoh, ketika terdapat lebih dari satu orang menghitung kecepatan pelari di titik yang sama, maka hasil waktu yang akan mereka hasilkan pada stopwatch akan berbeda-beda. Hal ini disebabkan oleh perbedaan kecepatan reaksi mereka, ketika mereka menekan tombol pada stopwatch. Penelitian sebelumnya, yang dilakukan oleh (jerry l. mayhew, jeremy j. houser, ben b. briney, tyler b. williams, fontaine c. piper, 2010). mengamati perbedaan waktu $0,19 \pm 0,14$ detik antara tangan operator satu dengan operator lainnya ketika mereka menguji dan 
Indria Herman, Tommy Apriantono, Widyawardana Adiprawita, Deni Kurnia One, Diyar Yasin, Syahruddin Syahruddin, Bagus Winata

menghitung kecepatan seorang pelari. Selanjutnya penelitian sebelumnya juga telah menjelaskan bahwa perbedaan waktu sebesar $(0,04-0,05 \mathrm{~s})$ antara penggunaan stopwatch dengan hasil yang dikeluarkan oleh timing gate saat mengumpulkan data kelompok pelari. Karena hal tersebut, timing gate lebih disukai karena dinilai lebih presisi dan memiliki nilai akurasi yang tinggi dibandingkan dengan stopwatch.

Dalam perkembangannya, timing gate memiliki beberapa model seperti single-beamed photocells, dual-beamed photocells, dan split-beamed and post-processing photocells. Dalam ketiga jenis timing gate tersebut, yang membedakan hanyalah jenis dan jumlah infrared sensor dan reflektornya. Penelitian sebelumnya banyak yang mengungkapkan terkait perbedaan daripada ketiga jenis timing gate tersebut, sebagai contoh (Haugen \& Buchheit, 2016) mengungkapkan perbandingan antara single-beamed photocells dan dual-beamed photocells. Dalam penelitiannya, (Haugen \& Buchheit, 2016) telah mengungkapkan perbedaan waktu absolut dalam kisaran - 0,05 hingga 0,06 detik terjadi antara single-beamed photocells dan dual-beamed photocells ketika melakukan pengukuran waktu $20 \mathrm{~m}$ pada atlet lari. Penelitian lainnya mengungkapkan juga bahwa split-beamed and postprocessing photocells dinilai lebih baik daripada kedua jenis timing gate lainnya. Sebagai contoh, penelitian yang dilakukan oleh (Earp \& Newton, 2012) yang menjelaskan bahwa split-beamed and postprocessing photocells memiliki tingkat akurasi yang lebih baik, karena dapat membeedakan antara cahaya noice dengan cahaya atau sensor yang dihasilkan terminal infrared sensor, sehingga dapat meminimalisasikan terjadinya bias cahaya. Hal ini sangat beralasan, mengingat beberpa penelitian yang mengkaji tentang single-beamed photocells dan dual-beamed photocells mengungkapkan bahwa perangkat tersebut masih memiliki kekurangan dalam melakukan filter cahaya ketika proses pembacaan berlangsung.

Secara lebih spesifik, peningkatan sistem otomatis untuk pembacaan waktu ketika melakukan sprint test memang sudah banyak dilakukan dan berkembang di dunia penelitian ilmu keolahragaan. Hal ini dikarenakan sistem pencatatan waktu otomatis dinilai lebih efektif untuk memfasilitasi para pelatih, atlet, ataupun praktisi olahraga dalam membantu mereka mengungkapkan hasil waktu ketika berlari. Sebagai contoh, penelitian yang dilakukan oleh (Ball et al., 2016) yang mengungkapkan bahwa $10 \mathrm{~Hz}$ GPS dan timing gates system lebih efisien dan presisi dalam memberikan atau menjawab waktu ratarata berlari 40-meter dibandingkan dengan radar gun. Meskipun dalam penelitian tersebut dilakukan pada uji test sprint 40-meter, dimana berbeda dengan uji test dalam penelitian yang kami lakukan (60meter sprint test), namun kami berasumsi bahwa penelitian kami telah mendukung penelitian sebelumnya untuk meyakinkan kepada setiap pelatih, atlet ataupun praktisi olahraga bahwa pencatatan waktu otomatis atau yang biasa disebut timing gate system adalah perangkat yang tepat dalam menjawab dan memberikan waktu ketika melakukan performa sprint.

Dengan beberapa fakta terkait perkembangan timing gate system tersebut, penelitian ini mencoba untuk mengembangkan suatu protipe alat sederhana yang dapat membantu para pelatih, praktisi olahraga, dan atlet untuk mengukur kecepatan sprint. Dalam proses perancangannya, protoipe ini memiliki konsep yang sederhana, dimana terminal sensor infrared akan memancarkan sinyal sensor kepada reflektor, sehingga menghasilkan garis sensor horizontal. Proses pembacaan waktu akan terbaca ketika peserta melewati sensor tersebut, sehingga alat ini dapat membaca kecepatan dan mengetahui grafik percepatan yang dilakukan oleh peserta. Meskipun alat ini sudah berhasil untuk membaca waktu kecepatan setiap peserta, namun kami juga menyadari bahwa penelitian ini masih terdapat kekurangan, seperti dimungkinkannya ketika proses pengambilan data, terjadi error machine ketika proses subjek berlari dan melewati sensor, sehingga proses pembacaan waktu menjadi delay dan menjadi pertanyaan serta perdebatan bagi para pelatih ataupun praktisi olahraga. Namun hal ini sejatinya cukup diwajarkan, mengingat dalam penelitian ini masih dalam mengusung konsep prototipe, dan belum dapat dilakukan uji perbandingan validasi dengan perangkat lainnya yang sudah memiliki sertifikat validasi dari badan perusahaan tertentu. Kejadian serta kekurangan tersebut, didukung oleh penelitian sebelumnya, yang dilakukan oleh Haugen, dkk (Haugen \& Buchheit, 2016). Dalam penelitian tersebut menjelaskan bahwa kewajaran error machine dalam proses pelaksanaan pengambilan waktu ketika berlari khususnya pada saat melewati gate start pada prototipe timing gate system. Secara lebih spesifik, Haugen, dkk menjelaskan bahwa error machine tersebut dapat diakibatkan oleh perbedaan posisi tubuh sprinter ketika melakukan start, sehingga hal tersebut dapat membuat perbedaan proses komunikasi pada prototipe timing gate system. Dampak daripada perbedaan proses komunikasi tersebutlah yang menyebabkan error machine dalam proses pembacaan waktu ketika melakukan start. 


\section{Jurnal Keolahragaan 9 (1), 2021 - 41}

Indria Herman, Tommy Apriantono, Widyawardana Adiprawita, Deni Kurnia One, Diyar Yasin, Syahruddin Syahruddin, Bagus Winata

Karena pada penelitian ini kami menyadari bahwa terdapat kekurangan, namun kami dapat meyakinkan bahwa error machine tersebut dapat dihindari ketika perangkat prototipe track trimer ini selalu dilakukan kalibrasi sebelum melakukan proses uji coba sprinter kepada setiap subjek. Di sisi lain, kami mendorong bahwa di waktu yang akan datang, tingkat presisi dan keakurasian prototipe track trimer dapat ditingkatkan, sehingga harapan kami, para pelatih ataupun praktisi olahraga tidak perlu untuk melakukan proses kalibrasi yang terlalu sering ketika melakukan pengujian sprinter. Penelitian selanjutnya selalu diharapkan trimer untuk membandingkan track yang dibuat dengan harga ekonomis ini dengan track trimer yang sudah tervalidasi dan memiliki izin edar dari perusahaan. Harapan tersebut diyakinkan, agar permasalahan pelatih ataupun praktisi olahraga dalam membeli track trimer dengan harga yang tinggi dapat segera diatasi dengan keberadaannya track trimer dengan harga ekonomis ini.

\section{SIMPULAN}

Penelitian research and development terkait pengembangan pencatatan waktu otomatis dalam penelitian ini, menunjukkan bahwa pencatatan waktu otomatis dapat dibuat dengan harga ekonomis, dan dapat digunakan untuk mengukur kecepatan lari 60-meter. Pengembangan lebih lanjut terkait kematangan tingkat presisi dan akurasi prototipe ini diperlukan agar dapat menghasilkan alat pengukuran yang baik untuk atlet, pelatih dan praktisi olahraga lainnya.

\section{DAFTAR PUSTAKA}

Altmann, S., Spielmann, M., Engel, F. A., Neumann, R., Ringhof, S., Oriwol, D., \& Haertel, S. (2017). Validity of Single-Beam Timing Lights at Different Heights. Journal of Strength and Conditioning Research, 31(7), 1994-1999. https://doi.org/10.1519/JSC.0000000000001889

Augen, T. H. A. H., Reitscha, F. E. B., \& Amozino, P. I. S. (2018). Power Force Velocity Profiling of Sprinting Athletes: Methodological and Practical Considerations When Using Timing Gates. Journal of Strength and Conditioning Research, 00(00), 1-5.

Ball, K., Aughey, R. J., Science, E., Living, A., Players, F., Pyne, D., ... Country, B. (2016). Validity of $10 \mathrm{HZ}$ GPS and Timing Gates for Assessing Maximum Velocity in Professional Rugby Union Players. International Journal of Sports Physiology and Performance, 12(6), 836-839.

Bergkamp, T. L. G., Niessen, A. S. M., den Hartigh, R. J. R., Frencken, W. G. P., \& Meijer, R. R. (2018). Comment on: "Talent Identification in Sport: A Systematic Review." Sports Medicine, 48(6), 1517-1519. https://doi.org/10.1007/s40279-018-0868-6

Earp, J. E., \& Newton, R. U. (2012). Advances in electronic timing systems: Considerations for selecting an appropriate timing system. Journal of Strength and Conditioning Research, 26(5), 1245-1248. https://doi.org/10.1519/JSC.0b013e3182474436

Fornasiero, A., Savoldelli, A., Modena, R., Boccia, G., Pellegrini, B., Schena, F., ... Fornasiero, A. (2017). Physiological and anthropometric characteristics of top-level youth cross-country cyclists cyclists. Journal of Sports Sciences, 00(00), 1-6. https://doi.org/10.1080/02640414.2017.1346271

Haugen, T., \& Buchheit, M. (2016). Sprint Running Performance Monitoring: Methodological and Practical Considerations. Sports Medicine, 46(5), 641-656. https://doi.org/10.1007/s40279015-0446-0

Haugen, T., Seiler, S., Sandbakk, Ø., \& Tønnessen, E. (2019). The Training and Development of Elite Sprint Performance: an Integration of Scientific and Best Practice Literature. Sports Medicine Open, 5(1). https://doi.org/10.1186/s40798-019-0221-0

Hetzler, R. K., Stickley, C. D., Lundquist, K. M., \& Kimura, I. F. (2008). Reliability and accuracy of handheld stopwatches compared with electronic timing in measuring sprint performance. Journal of Strength and Conditioning Research, 22(6), 1969-1976. https://doi.org/10.1519/JSC.0b013e318185f36c

Hopker, J. G., Coleman, D. A., Wiles, J. D., \& Galbraith, A. (2009). Familiarisation and reliability of sprint test indices during laboratory and field assessment. Journal of Sports Science and Medicine, 8(4), 528-532. 


\section{Jurnal Keolahragaan 9 (1), 2021 - 42}

Indria Herman, Tommy Apriantono, Widyawardana Adiprawita, Deni Kurnia One, Diyar Yasin, Syahruddin Syahruddin, Bagus Winata

Jacob, Y., Spiteri, T., Hart, N., \& Anderton, R. (2018). The Potential Role of Genetic Markers in Talent Identification and Athlete Assessment in Elite Sport. Sports, 6(3), 88. https://doi.org/10.3390/sports6030088

jerry l. mayhew, jeremy j. houser, ben b. briney, tyler b. williams, fontaine c. piper, and william $\mathrm{f}$. brechue 5. (2010). comparison between hand and electronic timing of 40-yd dash performance in college football players, 24(2), 447-451.

Johnston, K., Wattie, N., Schorer, J., \& Baker, J. (2018). Talent Identification in Sport: A Systematic Review. Sports Medicine, 48(1), 97-109. https://doi.org/10.1007/s40279-017-0803-2

Mann, D. L., Dehghansai, N., \& Baker, J. (2017). Searching for the elusive gift: advances in talent identification in sport. Current Opinion in Psychology, 16(17), 128-133. https://doi.org/10.1016/j.copsyc.2017.04.016

Mann, J. B., Ivey, P. J., Brechue, W. F., \& Mayhew, J. L. (2015). Validity and reliability of hand and electronic timing for 40-yd sprint in college football players. Journal of Strength and Conditioning Research, 29(6), 1509-1514. https://doi.org/10.1519/JSC.0000000000000941

Nagahara, R., Mizutani, M., Matsuo, A., Kanehisa, H., \& Fukunaga, T. (2018). Association of sprint performance with ground reaction forces during acceleration and maximal speed phases in a single sprint. Journal of Applied Biomechanics, 34(2), 104-110. https://doi.org/10.1123/jab.2016-0356

Spathis, J. G., Connick, M. J., Beckman, E. M., Newcombe, P. A., \& Tweedy, S. M. (2015). Reliability and validity of a talent identification test battery for seated and standing Paralympic throws. Journal of Sports Sciences, 33(8), 863-871. https://doi.org/10.1080/02640414.2014.969294

Storniolo, J. L., Pavei, G., \& Minetti, A. E. (2017). A “wearable” test for maximum aerobic power: Real-time analysis of a 60-m sprint performance and heart rate off-kinetics. Frontiers in Physiology, 8(NOV), 1-8. https://doi.org/10.3389/fphys.2017.00868

Syahruddin, S., Imam, I. S., Lungit, L., Ramdan, R. P., \& Bagus, B. W. (2019). Infrared sensor technology (IST) test as a tool for assessment of flexibility. Postepy Rehabilitacji, 33(3), 5-9. https://doi.org/10.5114/areh.2019.87743

Tiffany, A., \& Azmi, F. (2020). Diplomasi Publik Indonesia melalui Penyelenggaraan Asian Games 2018. Padjadjaran Journal of International Relations, 1(3), 202. https://doi.org/10.24198/padjir.v1i3.26193

Venckunas, T., Snieckus, A., Trinkunas, E., Baranauskiene, N., Solianik, R., Juodsnukis, A., ... Kamandulis, S. (2016). Interval Running Training Improves Cognitive Flexibility and Aerobic Power of Young Healthy Adults. Journal of Strength and Conditioning Research, 30(8), 2114 2121. https://doi.org/10.1519/JSC.0000000000001322

Zhang, Y., Liu, S., Zhang, Y. Q., Goulding, M., Wang, Y. Q., \& Ma, Q. (2018). Timing Mechanisms Underlying Gate Control by Feedforward Inhibition. Neuron, 99(5), 941-955.e4. https://doi.org/10.1016/j.neuron.2018.07.026 